\title{
The Effects of Hospital Organization on Treatment During COVID-19 Pandemic
}

\author{
- Recep Demirhan,' ๑ Berk Çimenoğlu, @ Erdal Yılmaz²
}

\author{
'Department of Thoracic Surgery, \\ University of Health Sciences, Kartal \\ Dr. Lütfi Kırdar Training and \\ Research Hospital, İstanbul, Turkey \\ ${ }^{2}$ Department of Emergency \\ Medicine, University of Health \\ Sciences, Kartal Dr. Lütfi Kırdar \\ Training and Research Hospital, \\ Istanbul, Turkey \\ Submitted: 10.05 .2020 \\ Accepted: 11.05 .2020 \\ Correspondence: Recep Demirhan, \\ Sağlık Bilimleri Üniversitesi Kartal \\ Dr. Lütfi Kırdar Eğitim ve Araştırma \\ Hastanesi, Göğüs Cerrahisi Kliniği, \\ İstanbul, Turkey \\ E-mail: recepdemirhan@hotmail.com

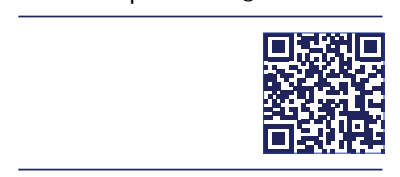 \\ Keywords: COVID-19; \\ hospital organisation; \\ pandemic.

\begin{abstract}
Objective: During the pandemic, various measures have been taken from the Ministry of Health to family health centers to minimize the effects of COVID-19 on both society and the healthcare system. It is crucial to quickly revise the hospital for such a large pandemic crisis to effectively treat patients that require hospitalization or intensive care. It is vital to act quickly, postpone the treatment of elective patients, and make room for patients affected by the pandemic. It is also important that the same diagnostic and treatment algorithms are followed all over the country to get reliable feedback. In this study, we share our experience in the successful management of the COVID-I9 outbreak between March II and May 7, 2020 , and investigate the role of the hospital organization in the success of the treatment.
\end{abstract}

Methods: Kartal Dr. Lütfi Kırdar Training and Research Hospital has been declared as a pandemic hospital by the Ministry of Health on March I I, 2020. To hospitalize patients diagnosed with COVID-19, 500 pandemic patient beds were arranged in 31 clinics.

Results: Until this date, 37350 polyclinic examinations have been performed for COVID-I9. The highest number of outpatient examinations was reached by 1656 on April 20, 2020. By the end of March, there was a noticeable increase in both the number of inpatient and outpatient clinics. Through pandemics, a total of 2536 patients was hospitalized, 163 of them were children. While 2087 (82\%) of our inpatients were discharged, 255 (10\%) of the patients are still being treated in our institution.

Conclusion: In conclusion, we think that in the diagnosis and treatment of COVID-19, having adequate physical space and sufficient workforce, and carrying out the treatment process with a good organizational chart will help us treat patients in a shorter time and will contribute to the reduction of morbidity and mortality.

\section{INTRODUCTION}

A previously unknown disease, called COVID-19, emerged in Wuhan, the capital city of the Hubei province of China. COVID-I 9 has affected the whole world by crossing the borders of China and requires healthcare organizations to take action. Various measures have been taken from the Ministry of Health to family health centers to minimize the effects of COVID-19 on both society and the healthcare system.

In December 2019, many patients began to apply to hospitals, with respiratory symptoms such as cough, fever and shortness of breath, in Wuhan, China. When the patients were questioned in detail, the common point in all was that the symptoms were developed after visiting the animal market where the wild animal products were sold. It was stated that the causative agent of this fast-transmitting disease was a new type of coronavirus, and this new disease was called COVID-19.['] On II March 2020, the World Health Organization (WHO) announced that this disease evolved into a pandemic. ${ }^{[2]}$
In the later stages of the pandemic, North America and Europe were seriously affected. ${ }^{[3]}$ Common characteristics of seriously affected countries are the insufficient health system and hospital organization. The measures to control COVID-19 disease, such as activating the surveillance system, encouraging the public to stay at home, improving hygiene measures and maintaining social distance, are vital in flattening the pandemic curve. In addition, it is crucial to quickly revise the hospital for such a large pandemic crisis to effectively treat patients that require hospitalization or intensive care.

The world has witnessed two more coronavirus outbreaks in the last 20 years. SARS (Severe Acute Respiratory Syndrome) originated from the Guangdong region of China in 2003. It has affected more than 8000 people in North America, Europe and Asia and killed more than 900 people. MERS (Middle East Respiratory Syndrome) was seen in Saudi Arabia in 2012 and caused approximately 500 deaths. However, unlike these diseases belonging to the coronavirus family, COVID-19 disease has spread much 
more widely, and as of 3 May 2020, there were 3.349 .786 cases and 238.628 deaths worldwide. Taking these pandemics into account, the possible effects of a possible moderate to severe influenza pandemic were modeled by the United States Ministry of Health in 2005. According to, 2009 and 2017 updates of this model, it is anticipated that 64 million Americans would be affected in such pandemic, hospitalization would be required by 800,000 (I.25\%) and intensive care by $160,000(0.25 \%){ }^{[4]}$

To get through this pandemic, countries' health infrastructure should have the capacity to provide for a large number of patients. In addition, it is vital to act quickly, postpone the treatment of patients without urgency, and make room for patients affected by the pandemic. In the event of a pandemic, hospitals need to rapidly increase their bed capacity. It is also important that the same diagnostic and treatment algorithms are followed all over the country to get reliable feedback.

Our hospital, which is one of the largest hospitals in Istanbul, has 1100 service beds, 210 intensive care beds and 3700 healthcare professionals. In this study, we share our experience in the successful management of the COVID-I9 outbreak between March II and May 7, 2020, and investigate the role of the hospital organization in the success of the treatment.

\section{MATERIALS AND METHODS}

In this study, details of the patients with COVID-19 were analyzed from I I March 2020 to 07 May 2020. The numbers of the hospitalized patients, performed PCR tests, total cases, and effected healthcare staff were assessed. Increase and decrease in these numbers and efficiency of the actions taken by hospital administration were evaluated. Importance of hospital organization in managing extraordinary situations, such as pandemic, was inspected.

\section{RESULTS}

Kartal Dr. Lütfi Kırdar Training and Research Hospital was declared as a pandemic hospital by the Ministry of Health on March I I, 2020. As from this date, all non-urgent patients were discharged to arrange beds for urgent patients affected by the pandemic. In addition to accepting outpatient applications, patients have been sent to our hospital by emergency ambulances continuously from every district of Istanbul. In order to hospitalize patients diagnosed with COVID-19, 500 pandemic patient beds were arranged at $3 \mathrm{I}$ clinics in our hospital. Moreover, some radiology and tomography units were spared for pandemic patients. Specific elevators and corridors were reserved for pandemic patients. Ten coronavirus outpatient clinics were opened so that patients could quickly be examined. Until this date, 37350 polyclinic examinations have been performed for COVID-19. The highest number of outpatient examinations was reached by 1656 on April 20, 2020. Afterwards, this number gradually decreased. There was a dramatic decline in the number of cases during the curfew days, and it was 953 on May 6, 2020 (Fig. I).

PCR test has been performed in a total of 30.225 patients. 3773 of these test results have been reported as positive. Due to the rapid increase in the number of patients at the beginning of the pandemic, the tests took 3-4 days to be reported. With the instructions of the Ministry of Health and the technical support of TÜSEB, a PCR laboratory was established in our hospital within three days, and the test results became available within one day, which helped

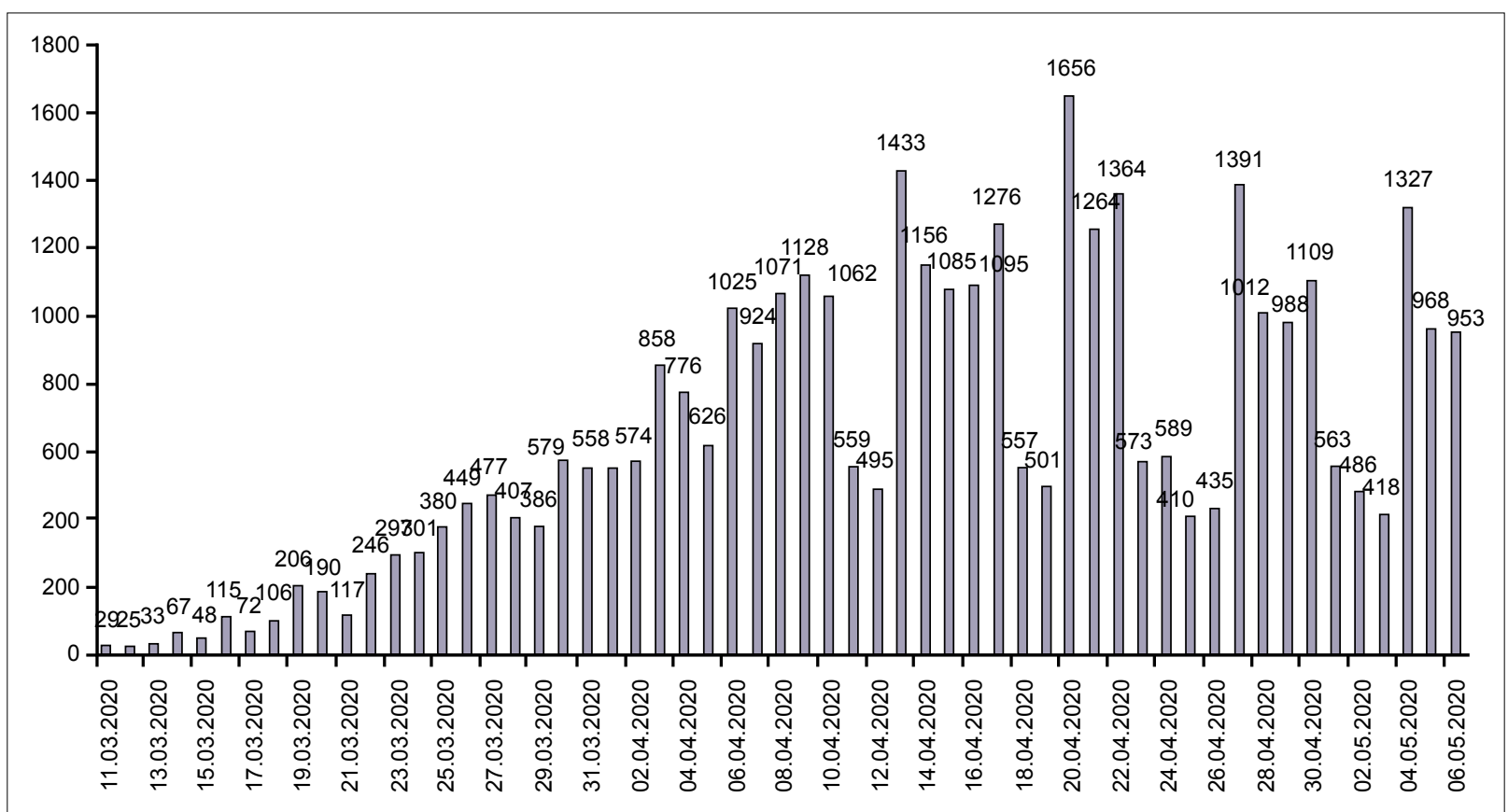

Figure 1. COVID-19 outpatient examinations by date $(n=37350)$. 


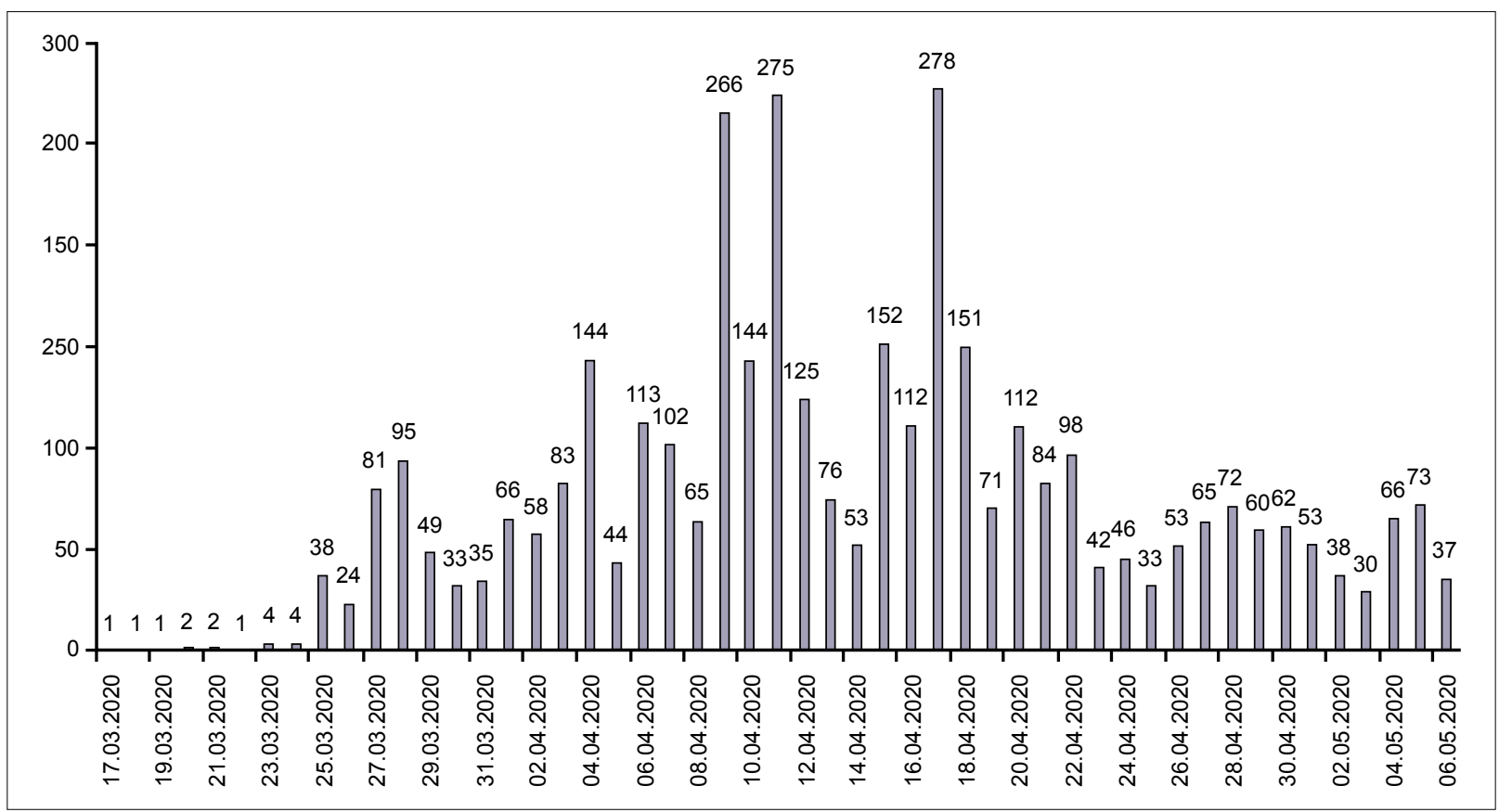

Figure 2. COVID-19 total case numbers $(n=3773)$.

us plan a quick treatment for the patients. Earlier diagnosis led earlier treatment (Figs. 2-4).

By the end of March, there was a noticeable increase in both the number of inpatient and outpatient clinics. These numbers have increased gradually in the following days, and the highest value was seen on April 8, 2020. While new clinics were put into service, treatment processes of inpatients were quickly completed to provide beds for newcomers. Meanwhile, the patients with good condition and saturation higher than $93 \%$ were sent home with medication for self-isolation. From this date onwards, the number of hospitalizations per day decreased step by step until May 6. Through pandemics, a total of 2536 patients were hospitalized, 163 of them were children. While 2087 (82\%) of our inpatients were discharged, 255 (10\%) patients are still being treated in pandemic clinics and pandemic intensive care units (Figs. 5, 6).

In our hospital, 213 patients were suffering from COVID-19 died. 75 of these patients were test positive and II 8 were test negative. In 20 patients, the swab sam-

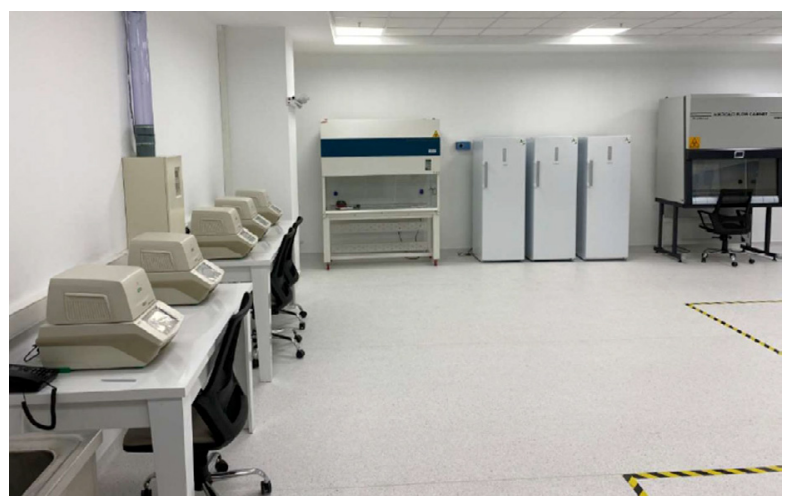

Figure 3. PCR laboratory. ple was reported to be insufficient, and the patients had died before a re-study.

Despite the use of personal protective equipment and all hygienic precautions, approximately 133 staff was infected. Treatment of 99 of our staff has been completed and they returned to work. Up to date, 34 hospital staff is currently being isolated and treated at home. Mortality has not been observed in our hospital staff.

While the average age of adult inpatients was 58 , our youngest patient was a 22-day-old baby. Our oldest patient was 101 years old. The average age of the patients in intensive care unit was 68 . The average age of the patients who died in the intensive care unit was found to be 70 . In our hospital, the mortality rate due to Coronavirus was $1.9 \%$. It was determined that advanced age and presence of comorbidity increases mortality. Diabetes, chronic obstructive pulmonary disease (COPD) and hypertension are the most common comorbid diseases in patients diagnosed with COVID-19. As the treatments of the patients were arranged, the treatment for these comorbidities was also carried out.

\section{DISCUSSION}

All necessary precautions are taken across Turkey to get through this pandemic with minimal damage and all kinds of healthcare services are reserved for preventive measures, diagnosis and treatment of COVID-19.

All healthcare facilities across the world have encountered abundant number of patients and mortality rate is higher at regions where hospital capacity is insufficient for many patients with COVID-19. As of February 16, 2020, there were a total of $7064 \mathrm{I}$ cases and 1772 deaths in China. 


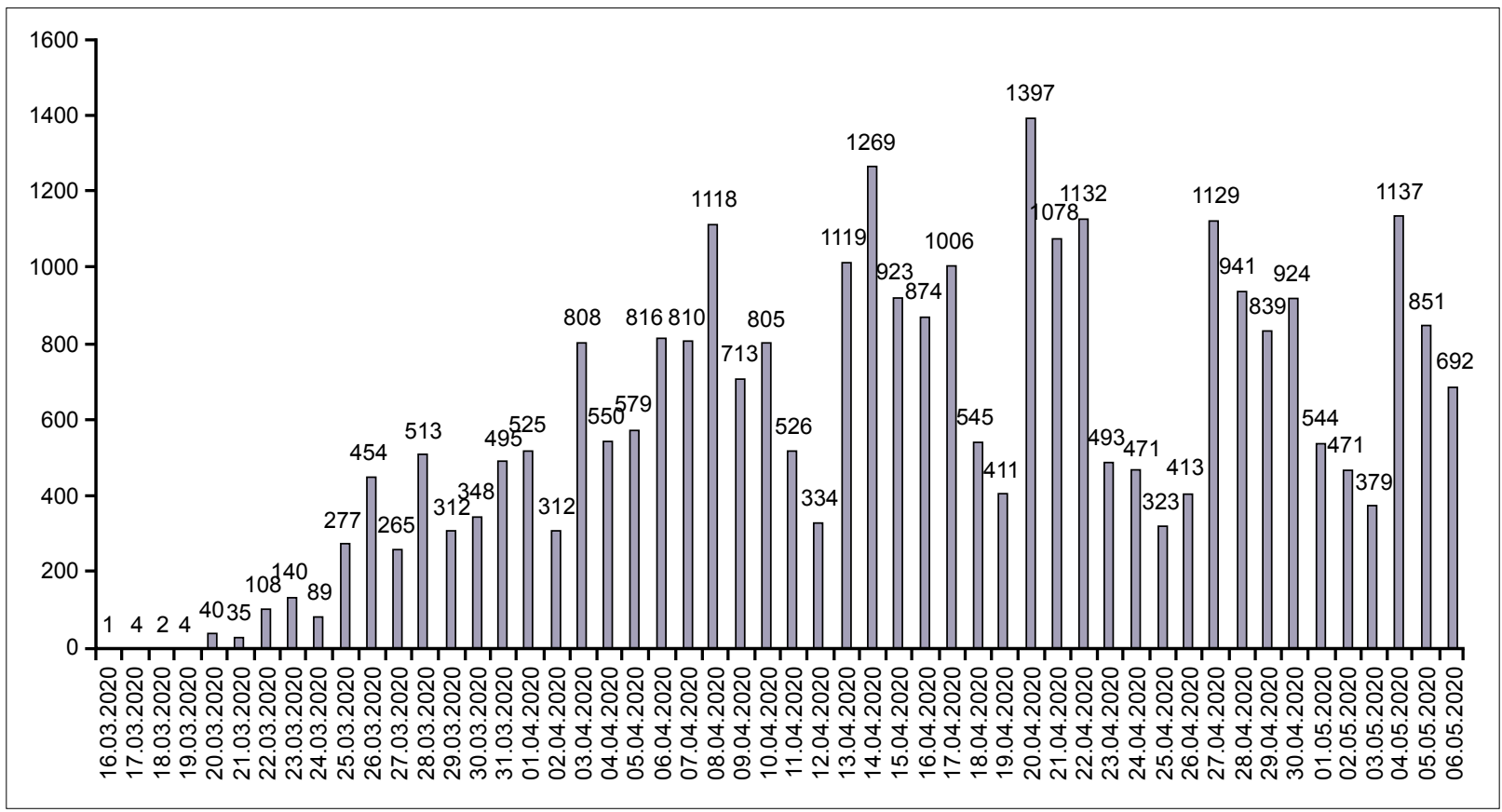

Figure 4. Covid-19 test numbers by date $(n=30255)$.

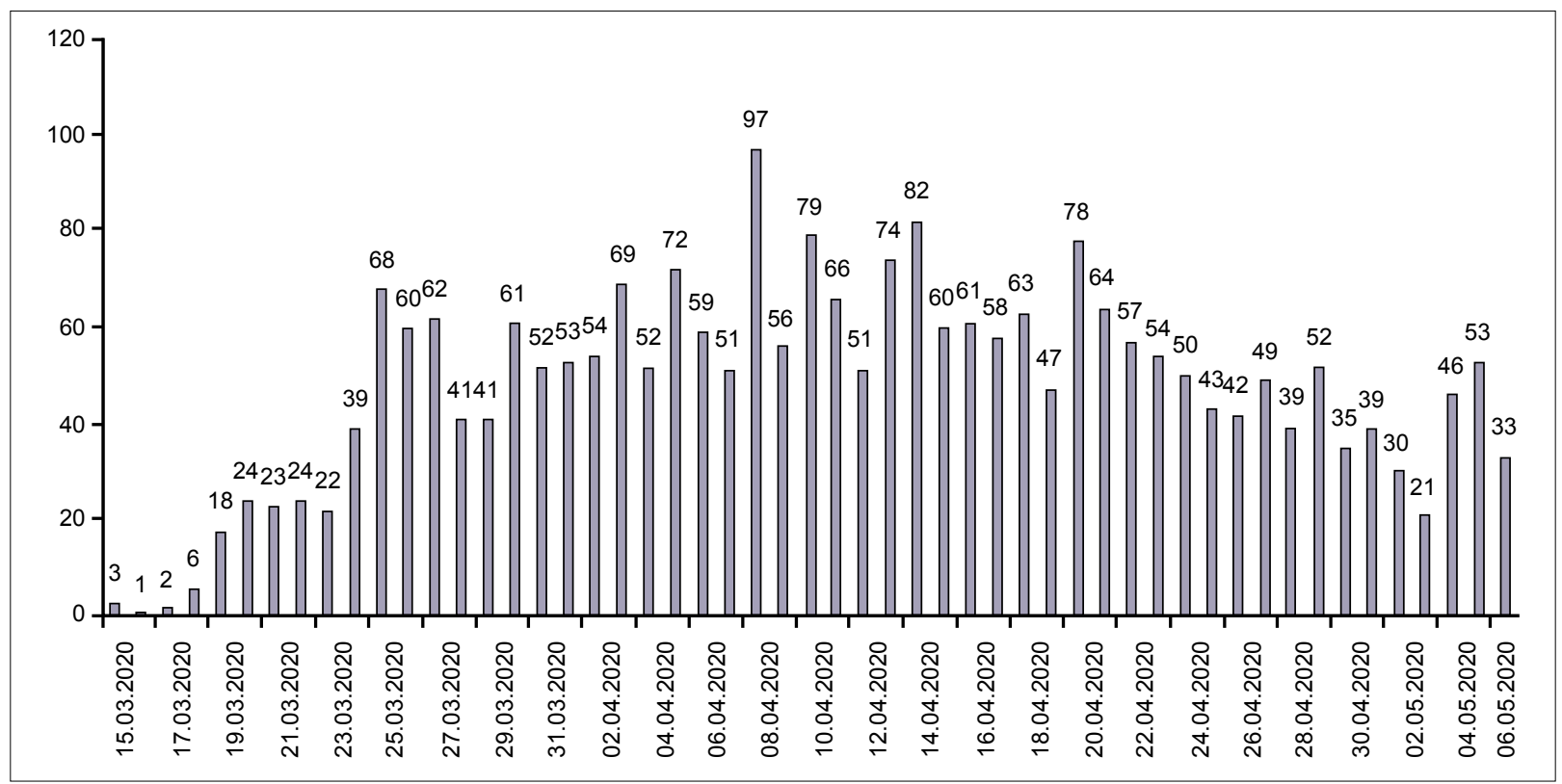

Figure 5. New hospitalization numbers by day $(n=2536)$.

Mortality rate was $2.5 \%$, whereas in Wuhan, epicenter of the pandemic, this rate was above $3 \%$ and in the cities of Hubei other than Wuhan, it was $2.9 \% .^{[5]}$ Similarly, mortality rate in Lombardy, epicenter of the pandemic in Europe, is specifically higher than other regions of Italy. ${ }^{[6]}$ Being caught unprepared and having scarce medical resources due to sudden increase in infected patients are two of the main reasons behind Wuhan's and Lombardy's high mortality rate compared to other regions of China and Italy. As of May 5, 2020, the mortality rate in Turkey was $2.7 \%$. In Kartal Dr. LütfiKırdar Training and Research Hospital, we have taken strict measures and implemented successful treatment algorithms, which helped us accomplish a mortality rate of $1.9 \%$.

A study conducted by the U.S. Department of Health and Human Services addresses challenges in healthcare facilities during the pandemic. Difficulties of the pandemic process, measures against these difficulties and the role of the government are discussed. The challenges encountered were basically severe shortages of testing supplies and extended wait time for results, widespread shortages of personal protective equipment (PPE), difficulty maintaining adequate staffing and supporting staff for the increased number of patients, difficulty maintain- 


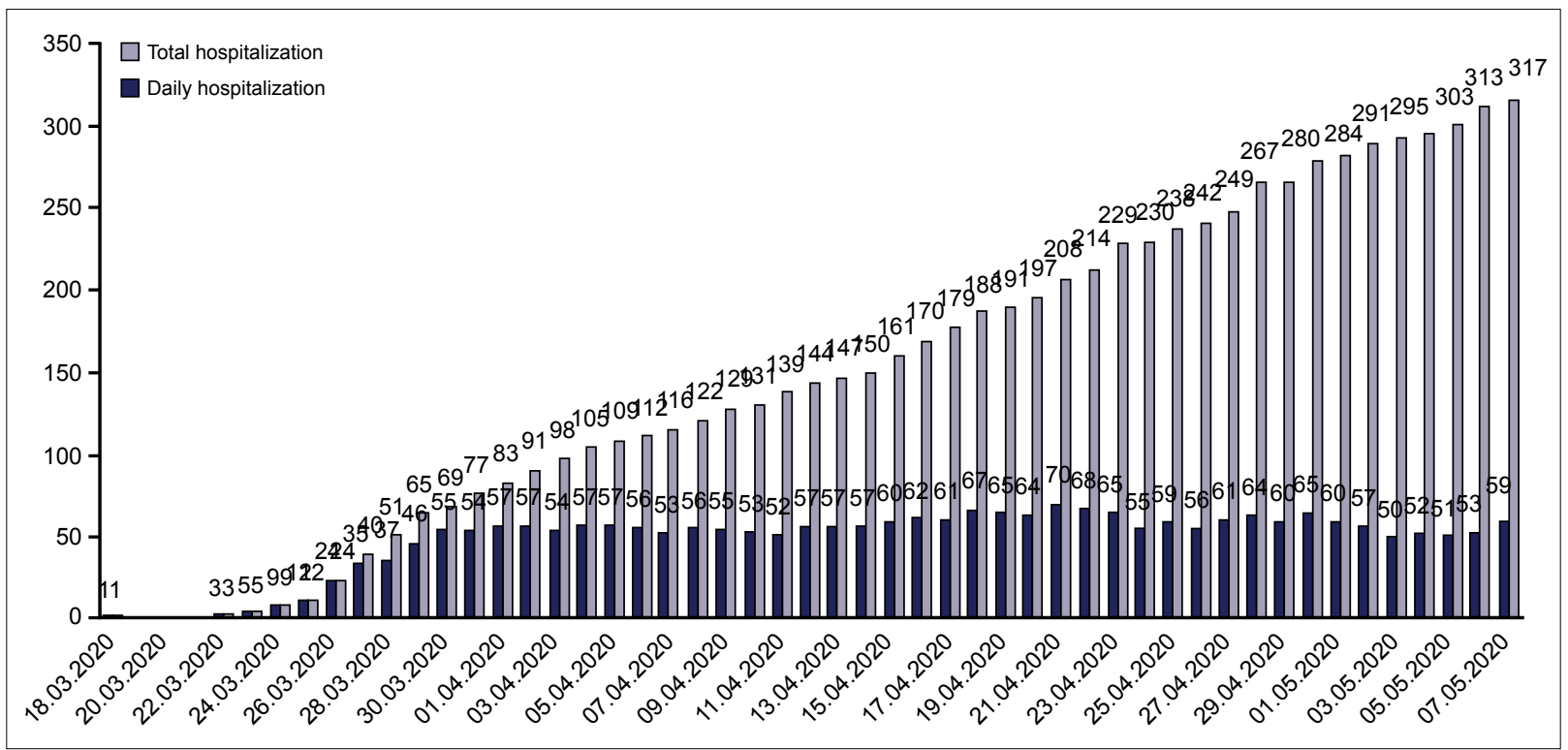

Figure 6. Number of patients hospitalized in the pandemic intensive care units by date $(n=317)$.

ing and expanding hospital capacity to treat patients and shortages of logistic support and critical supplies such as ventilators. Measures that hospital administrators have to take are listed as securing necessary PPE, ensuring the adequate number of hospital staff, supporting hospital staff, managing patient flow and hospital capacity and securing ventilators and alternative equipment to support patients. Responsibilities of the government are providing tests, supplies and equipment, allocating adequate workforce, maintaining the capacity of facilities and financial assistance. ${ }^{[7]}$ To avoid such challenges, we quickly prepared our hospital for this pandemic crisis. All evacuable wards and intensive care units were allocated for pandemic patients. We emptied 31 wards to provide 500 beds for pandemics and transformed an area of the hospital to a brand new intensive care unit. Necessary devices, such as ventilators and monitors, have quickly been obtained. Thus, this expanded capacity of the hospital helped us find beds for all patients requiring inpatient treatment. Meanwhile, we activated 10 new outpatient clinics so that patients did not have to wait in long lines in front of examination rooms.

During the pandemic, lack of hospital staff, ICU beds, ventilators, diagnostic tests and appropriate medication could be encountered. However, healthy medical staff will most likely be the limiting factor in a such situation. ${ }^{[8]}$ According to the guidelines of the Centers for Disease Control and Prevention (CDC), patients with proven or suspected COVID-19 diagnosis should be examined using gloves, N95 mask, face shield and goggles. ${ }^{[9]}$ In countries where PPE's are hard to find, healthcare workers are facing two drawbacks. The first drawback is the overwhelming burden of the enormous number of patients and the second drawback is the risk of infection. ${ }^{[10]}$ All healthcare workers received PPE immediately and lectured about COVID- 19 prevention. With the help of these measures, we were able to keep the number of infected healthcare staff at a minimum level of $3.6 \%$. During the pandemic, we implemented rotations on healthcare personnel to maintain a daily routine and avoid any impediment. Furthermore, patient-based daily meetings and rounds were organized by our hospital's COVID-19 pandemic scientific board. Treatment modalities have constantly been updated in the light of the Ministry of Health's guidelines on COVID-19, preventing any delays in treatment. This is one of the biggest reasons behind us achieving such a low mortality rate.

Favipiravir, which inhibits RNA polymerase activity, plays an important role in COVID- 19 treatment concerning high antiviral activity and fast viral clearance. ${ }^{[1]}$ While Favipiravir cannot be found in some countries, many countries use it only in the ICU. In Turkey, we had the opportunity to initiate this treatment to appropriate patients at the early course of the disease and this helped us avoid clinical deterioration in many patients. Furthermore, we achieve beneficial results in patients in ICU with prone positioning, high-flow oxygen treatment and plasma therapy. ${ }^{[12-14]}$ The use of IL-6 (tocilizumab) had a positive effect on some patients. In addition, immune systems of the patients were supported by high dose vitamin $C$ treatment (30 g/day). Anticoagulant agents, such as enoxaparin, were added to the treatment of patients with high d-dimer values, which led to a reduction in sudden deaths. With the help of these medications, our treatment success rate has increased in the pandemic intensive care unit. We may also say that the number of patients requiring intubation decreased. This was one of the secrets to our success in COVID-19 treatment. A timely move of the Ministry of Health to provide necessary medication and medical equipment to our hospital was a crucial factor in this success.

Our hospital has regularly been disinfected to cover all areas since the beginning of the process to protect the health of patients and hospital staff. Elevators, dining hall, 
chairs and polyclinic rooms are arranged according to social distancing rules and disinfected. All meetings and organizations with social content were also canceled.

During the pandemic crisis, immediate actions should be taken by hospital administrators. It is important to quickly put new outpatient clinics to use, establish new PCR laboratories and to postpone diagnosis and treatment of elective patients. Hospital administrators should eliminate medical equipment/device deficiencies and physical space shortages by taking quick decisions. At the same time, psychosocial support should be provided for hospital staff. In conclusion, we think that in the diagnosis and treatment of COVID-19, having adequate physical space and sufficient workforce, and carrying out the treatment process with a good organizational chart will help us treat patients in a shorter time and will contribute to the reduction of the morbidity and mortality.

Ethics Committee Approval

Approved by the local ethics committee (date: I3.05.2020 no: 2020/5 |4/177//7).

Peer-review

Internally peer-reviewed.

Authorship Contributions

Concept: R.D.; Design: R.D., B.Ç.; Supervision: R.D.; Materials: E.Y., B,Ç.; Data: R.D.; Analysis: E.Y.; Literature search: R.D., B.Ç.; Writing: R.D., B.Ç.; Critical revision: R.D.

Conflict of Interest

None declared.

\section{REFERENCES}

1. Zhao JY, Yan JY, Qu JM. Interpretations of "Diagnosis and Treatment Protocol for Novel Coronavirus Pneumonia (Trial Version 7)". Chin Med J (Engl) 2020 Apr 14. [Epub ahead of print], doi: 10.1097/CM9.0000000000000866. [CrossRef]

2. World Health Organization WHO Director-General's opening remarks at the media briefing on COVID-19 - 11 March. Available aththtps:/wwwwho.int/dg/speeches/detail/who-director-general-s-opening-remarks-at-the-media-briefing-on-covid-19---11-march-2020. Accessed Apr 12, 2020
3. WHO. Coronavirus disease 2019 (COVID-19) situation report-104. Available at: https://www.who.int/docs/default-source/ coronaviruse/situation-reports/20200503-covid-19-sitrep-104. pdf?sfvrsn=53328f46_4. Accessed Apr 12, 2020.

4. Pandemicinfluenza plan: 2017 update. Washington, DC: Department of Healthand Human Services, 2017. Available at: https:// www.cdc.gov/flu/pandemic-resources/pdf/pan-flu-report-2017v2. pdf. Accessed Apr 12, 2020.

5. Ji Y, Ma Z, Peppelenbosch MP, Pan Q. Potential association between COVID-19 mortality and health-care resource availability. Lancet Glob Health 2020;8:e480. [CrossRef]

6. Odone A, Delmonte D, Scognamiglio T, Signorelli C. COVID-19 deaths in Lombardy, Italy: data in context. Lancet Public Health 2020 Apr 24. [Epub ahead of print], doi: 10.1016/S2468-2667(20)300992. [CrossRef]

7. Christi A. Grimm. U.S. Department of Healthand Human Services. Hospital Experiences Responding to the COVID-19 Pandemic: Results of a National Pulse Survey March 23-27, 2020. Available at: https://oig.hhs.gov/oei/reports/oei-06-20-00300.pdf. Accessed Apr 12,2020

8. Emanuel EJ, Persad G, Upshur R, Thome B, Parker M, Glickman A, et al. Fair Allocation of Scarce Medical Resources in the Time of Covid-19. N Engl J Med 2020 Mar 23. [Epub ahead of print], doi: 10.1056/NEJMsb2005114. [CrossRef]

9. Centers for Disease Control and Prevention. Interim infection prevention and control recommendations for patients with confirmed coronavirus disease 2019 (COVID-19) or persons under investigation for COVID-19 in healthcare settings. Available at: https:// www.cdc.gov/coronavirus/2019-ncov/infection-control/control-recommendations.html. Accessed Apr 12, 2020.

10. Adams JG, Walls RM. Supporting the Health Care Workforce During the COVID-19 Global Epidemic. JAMA 2020 Mar 12. [Epub ahead of print], doi: 10.1001/jama.2020.3972. [CrossRef]

11. Şimşek Yavuz S, Ünal S. Antiviral treatment of COVID-19. Turk J Med Sci 2020;50:611-9. [CrossRef]

12. Ghelichkhani P, Esmaeili M. Prone Position in Management of COVID-19 Patients; a Commentary. Arch Acad Emerg Med 2020;8:e48.

13. Geng S, Mei Q, Zhu C, Yang T, Yang Y, Fang X, et al. High flow nasal cannula is a good treatment option for COVID-19. Heart Lung 2020 Apr 11. [Epub ahead of print], doi: 10.1016/j.hrtlng.2020.03.018.

14. Chen L, Xiong J, Bao L, Shi Y. Convalescent plasma as a potential therapy for COVID-19. Lancet Infect Dis 2020;20:398-400. [CrossRef] 


\section{COVID-19 Pandemi Sürecinde Hastane Organizasyonunun Tedaviye Etkisi}

Amaç: Tüm dünyayı etkileyen COVID- 19 hastalığı sağlık kurumlarının bu konuda önemli tedbirler almasını gerekli kılmaktadır. Sağlık Bakanlı̆ı düzeyinden aile sağ|ı̆̆ı merkezlerine kadar alınan çeşitli tedbirlerle koronavirüs hastalığının hem toplum hem de sağlık sistemi üzerindeki etkilerinin en aza indirgenmesi hedeflenmiştir. Pandemiden ağır etkilenen ülkelerin ortak özellikleri sağlık sisteminin ve hastane organizasyonunun yetersiz kalmasıdır. Servis veya yoğun bakım gerekliliği olan hastaların tedavilerinin etkin bir şekilde yapılması amacıyla böyle büyük pandemik krizler için hastaneyi hızlıca uygun hale getirmek önemli rol oynar. Süratli bir şekilde harekete geçip, aciliyeti olmayan hastaların tedavilerini erteleyip, pandemiden etkilenen hastalara yer açılması gerekmektedir. Ayrıca oluşturulan tanı ve tedavi algoritmalarının tüm ülkede aynı hastalık grubunda aynı algoritmayı izlemesi geri dönüş açısından da önemlidir. Bu çalışmada II Mart - 07 Mayıs 2020 arasında COVID- I9 salgınının başarılı bir şekilde yönetilmesinde deneyimlerimizi aktardık ve hastane organizasyonunun tedavinin başarılı olmasındaki rolünü araştırdık.

Gereç ve Yöntem: I I Mart 2020 tarihinde Kartal Dr. Lütfi Kırdar Eğitim ve Araştırma Hastanesi, Sağlık Bakanlığı tarafından pandemi hastanesi olarak ilan edilmiştir. COVID- 19 tanısı konulan hastaların yatırılması için hastanemizde hızlıca 31 klinikte 500 pandemi hasta yatağı oluşturuldu.

Bulgular: Bu tarihe kadar COVID-19 nedeni ile toplam 37350 poliklinik muayenesi yapıldı. 20 Nisan 2020'de 1656 ile en yüksek poliklinik muayene sayısına erişildi. Mart ayının sonlarına doğru hem COVID-19 polikliniklerimize başvuran hasta sayısında hem de pandemi kliniklerinde yatan hasta sayısında gözle görülür bir artış meydana geldi. Bu süreçte 2536 hasta yatarak tedavi edildi. Bu hastaların I63'ü çocuktu. Yatan hastalarımızın 2087'si (\%82) şifa ile taburcu edildi, 255 (\% 10) hastanın ise pandemi kliniklerinde ve pandemi yoğun bakım ünitelerinde tedavilerine devam edilmektedir.

Sonuç: Sonuç olarak COVID-19 saptanan hastaların tanı ve tedavisi konusunda fiziki mekan ve sağılk ekibi olarak yeterli bir konumda olmak ve iyi bir organizasyon şeması ile tedavi sürecini yürütmek hastaların kısa sürede tedavi olmasına neden olduğu gibi, morbidite ve mortalitenin azalmasına katkı sağlayacağı kanaatindeyiz.

Anahtar Sözcükler: COVID-19; hastane organizasyonu; pandemi. 